\title{
Inventory of Microbiological Water Quality from Some Boreholes in Zinder Region in the Republic of Niger
}

\author{
Salifou Issa ${ }^{1,}$ *, Sèmiyou Ayélé Osseni ${ }^{4}$, Adamou Zanguina ${ }^{2}$, Ibrahim Natatou ${ }^{2}$, Mousa Boukari ${ }^{1}$, \\ Daouda Mama ${ }^{1}$, Dominique Sohounhloué ${ }^{3}$ \\ ${ }^{1}$ National institute of the Water (NIW), University of Abomey-Calavi, Cotonou, Benin \\ ${ }^{2}$ Department of Chemistry, Faculty of Science and Techniques, Abdou Moumouni University, Niamey, Niger \\ ${ }^{3}$ Polytechnic school of Abomey-Calavi (PSAC), University of Abomey-Calavi, Cotonou, Benin \\ ${ }^{4}$ Department of Chemistry, University of Abomey-Calavi, Cotonou, Benin
}

Email address:

sirete2000@yahoo.fr (S. Issa)

${ }^{*}$ Corresponding author

\section{To cite this article:}

Salifou Issa, Sèmiyou Ayélé Osseni, Adamou Zanguina, Ibrahim Natatou, Mousa Boukari, Daouda Mama, Dominique Sohounhloué. Inventory of Microbiological Water Quality from Some Boreholes in Zinder Region in the Republic of Niger. American Journal of Applied Chemistry. Vol. 6, No. 3, 2018, pp. 96-101. doi: 10.11648/j.ajac.20180603.13

Received: June 1, 2018; Accepted: June 21, 2018; Published: July 18, 2018

\begin{abstract}
The present work deals with the current microbiological status of boreholes found in Zinder region in the Republic of Niger. The study is centered on thirty (30) holes selected to monitor the variation in the microbiological quality of the water. For that the parameters studied are total coliforms, faecal coliforms and E-coli. From these parameters is calculated the microbiological quality index (MQI) by Bovesse and Depelchin method 1980. The variations of the faecal contamination as well as those of the various parameters on the whole of the drillings are represented on maps of spatial distribution. On the whole of the drilling the (MQI), is zero which denotes the absence of any faecal contamination. On $96.67 \%$ of the holes is observed the presence of total sprouts with structures having a rate that exceeds $100 \mathrm{CFU}$ per $100 \mathrm{ml}$ of sample. The presence of total coliforms is also observed on $36.67 \%$ of the boreholes with structures presenting more than $100 \mathrm{CFU}$ per $100 \mathrm{ml}$ of sample. Although these waters do not have faecal contamination, their microbiological quality does not meet the recommended standards for drinking water.
\end{abstract}

Keywords: Water, Microbiological Pollution, Microbiological Quality Index, Zinder Region, Niger

\section{Introduction}

Water is a rare resource common to all humanity [1]. Access to clean water is the central in most public health problems in developing countries [2]. The World Health Organization estimates that nearly 500 million people face water-borne infectious diseases each year, and that 20 million people die from them, making the microbiological quality of water a leading public health concern worldwide $[3,4,5]$. In addition, bacterial contamination in water is a natural phenomenon, where humans play the role of primary contaminants, but also secondary receptor of bacteria present in the medium [3]. However, the preservation of water quality is necessary for sustainable development and the maintenance of health [6]. Unfortunately, in Africa south of the Sahara, more than a third of the population suffers from serious illnesses due to the poor quality of this essential substance for human life [7]. Thus, the most common microbiological infections related to water, are caused by three main types of microorganisms: bacteria, viruses and protozoa $[8,9]$.

Groundwater is traditionally the preferred source of water for drinking water supply because it is safer from pollutants than surface water [10]. The region of Zinder (Niger), the study area obtains much of its drinking water from groundwater [11]. However, the microbiological monitoring of these waters does not exist. Among the bacteria that may be found in water, we analyzed the groups of total germs, total coliforms and E-coli.

The present study aims to determine the state of the 
microbiological quality of groundwater from the works used by the Ministry of Hydraulics and Sanitation to serve these populations in drinking water.

\section{Material and Methods}

\subsection{Material}

The study area is in Zinder region (Figure 1).

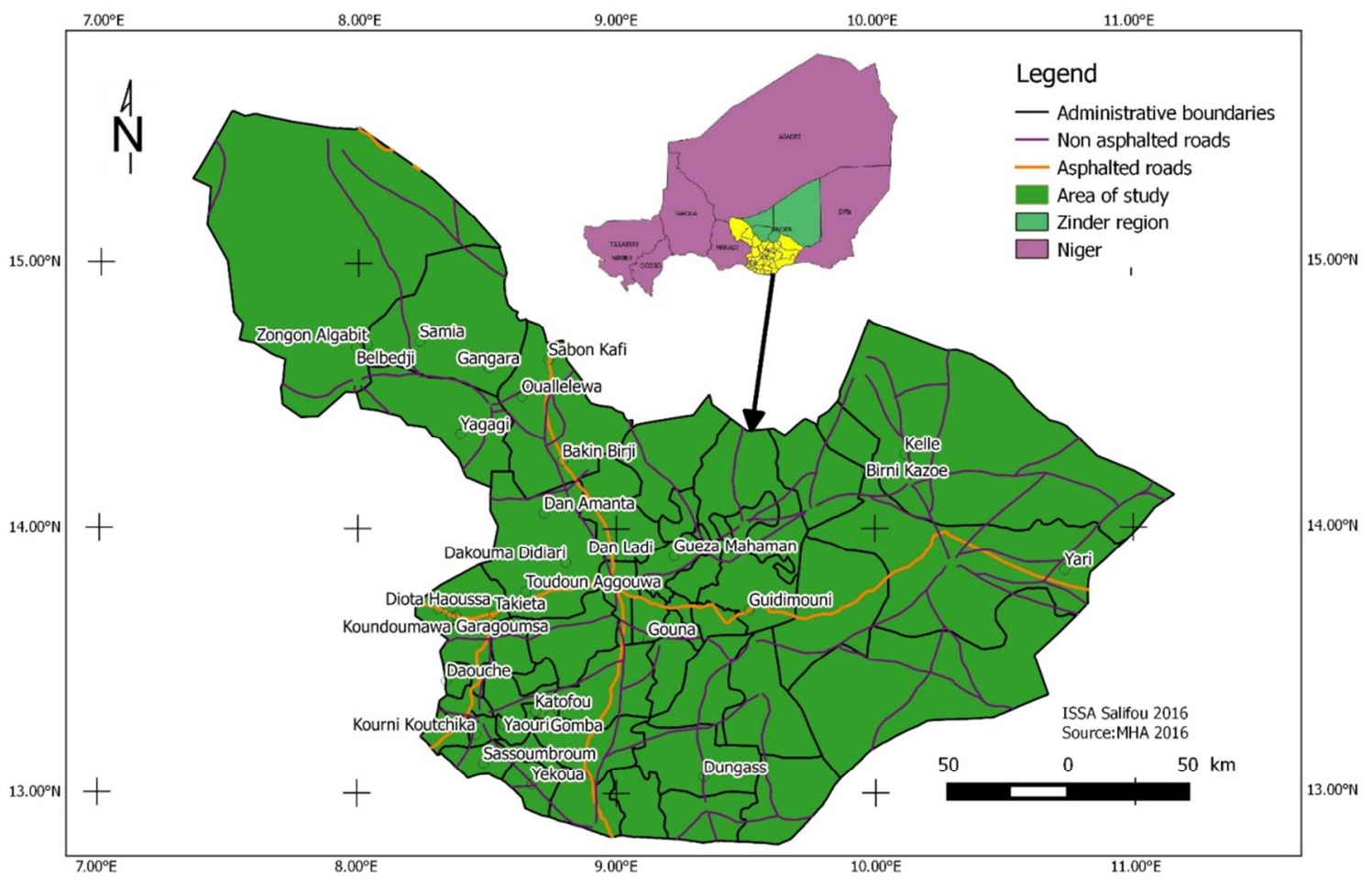

Figure 1. Map of the geographical location of the study area.

The study is centered on thirty (30) sampled points that already exist in the field. These points are divided into two types: cemented boreholes with human motricity and boreholes equipped with a mini drinking water supply point
(AEP).

The following map (Figure 2) presents the distribution of the various sampled boreholes selected for this study.

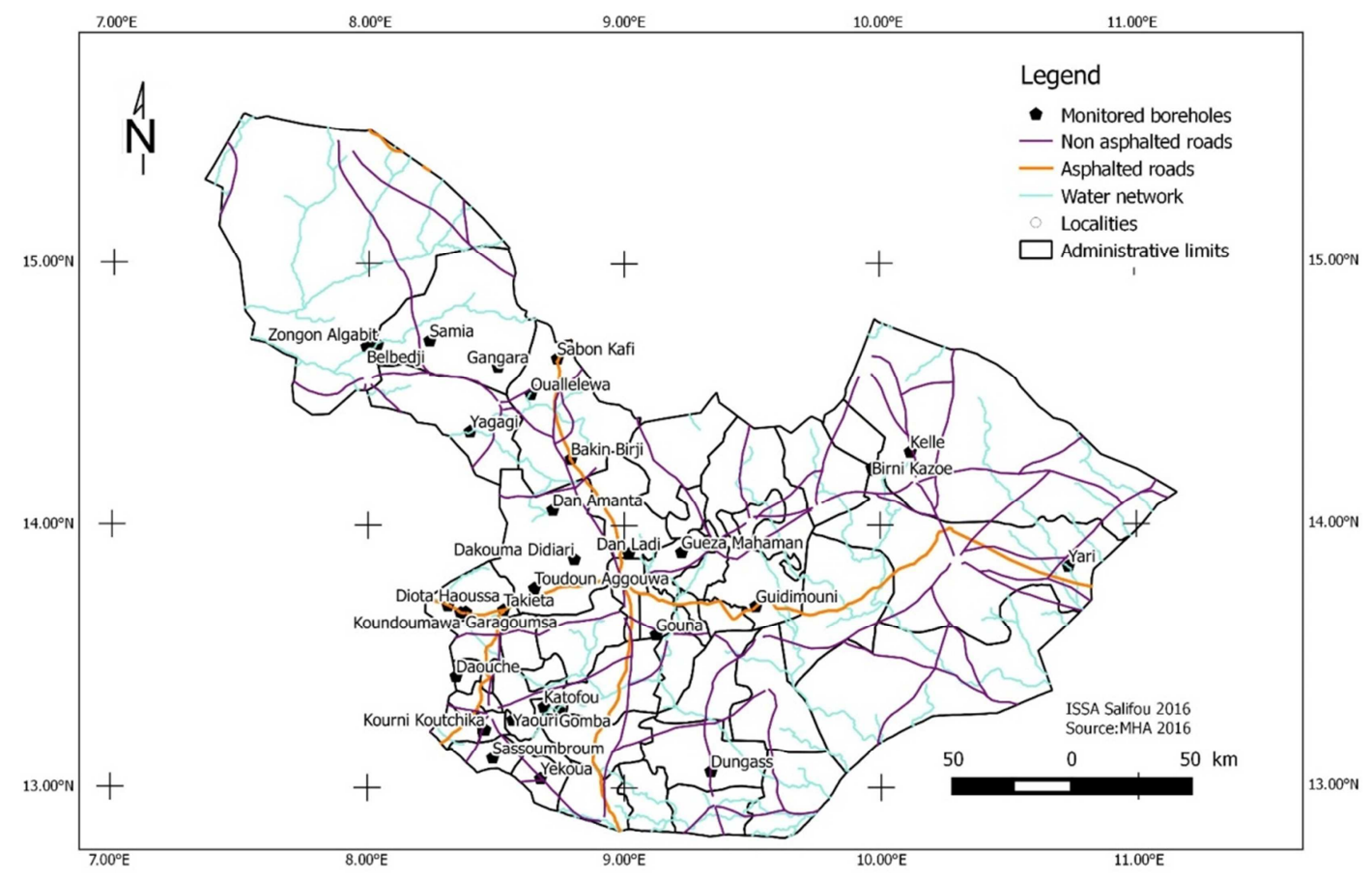

Figure 2. Location map of sampled drill holes. 


\subsection{Methods}

Samples of water samples for bacteriological analysis are made as described by SEEN [12]. As part of the study, three bacteriological measurements were performed on these structures in 2015. The parameters analyzed here were total germs, total and faecal coliforms, and E-coli by the filter membrane coliometry method.

The methods of data processing were based on the indication of fecal contamination (Bovesse and Depelchin, 1980), called microbiological quality index (MQI). The (MQI) is calculated from the concentrations of water in total fecal coliforms and E-coli.

Five classes of concentrations were defined for each of these parameters (Table 1). The (MQI) is the average of the class numbers of each parameter. The classification of the polluted parameters is done according to five quality classes (table 2) corresponding to the standard colors (figure 3).

And secondly on the graphical representation of the variations of the different parameters measured on these waters. The qgis 12.2 and microsoft excel software made it possible to produce the various maps of location and spatial distribution of the parameters measured on these waters.

Table 1. Quality classes corresponding to the different parameters.

\begin{tabular}{llll}
\hline Classes & Total bacteria $/ \mathbf{m l}$ & $\begin{array}{l}\text { Faecal } \\
\text { Coliforms } / \mathbf{m l}\end{array}$ & $\begin{array}{l}\text { Faecal } \\
\text { Streptococci } / \mathbf{m l}\end{array}$ \\
\hline 5 & $<2000$ & $<100$ & $<5$ \\
4 & $2000-9000$ & $100-500$ & $5-10$ \\
3 & $9000-45000$ & $500-2500$ & $10-50$ \\
2 & $45000-360000$ & $2500-20000$ & $50-500$ \\
1 & $>360000$ & $>20000$ & $>500$ \\
\hline
\end{tabular}

Table 2. The classification of polluted parameters according to five classes of quality (MQI).

\begin{tabular}{ll}
\hline M QI & faecal Contamination \\
\hline $4,3-5,0$ & zero \\
$3,5-4,2$ & Low \\
$2,7-3,4$ & Moderate \\
$1,9-2,6$ & Strong \\
$1,0-1,8$ & Very strong \\
\hline
\end{tabular}

\begin{tabular}{|l|}
\hline Zero pollution \\
\hline Low pollution \\
\hline Moderate pollution \\
\hline Strong pollution \\
\hline Very strong pollution \\
\hline
\end{tabular}

Figure 3. Quality classes corresponding to standard colors.

\section{Results and Discussion}

The interpretations of the calculated values of the microbiological water quality index, from the results measured on the water sampled on each borehole are shown on the map below.

The interpretation of the microbiological quality index (MQI) values of the studied boreholes indicates the level of faecal contamination of these waters (Figures 4).

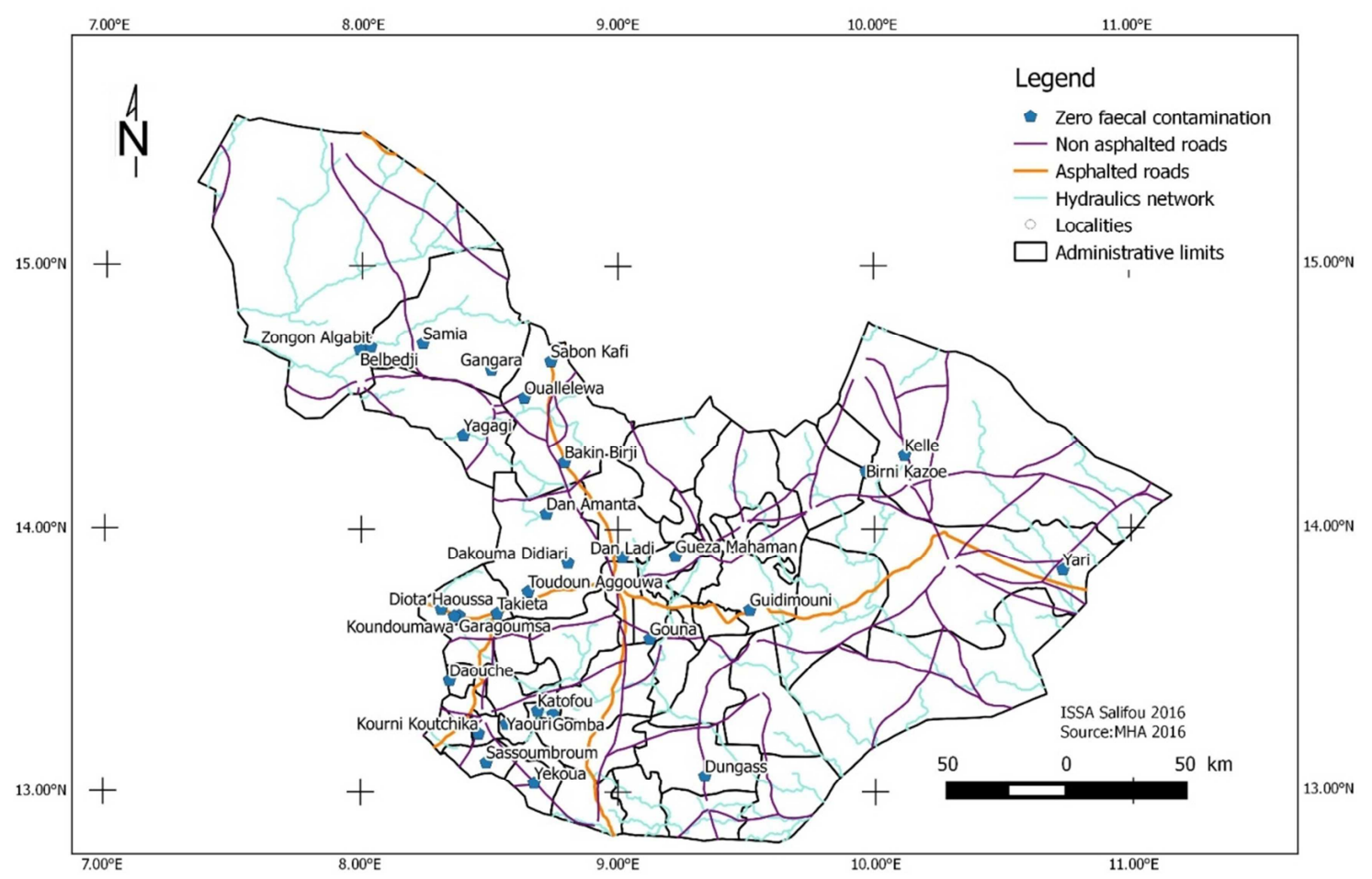

Figure 4. Map of variation in fecal contamination of boreholes. 
On all drilling $4.3<\mathrm{IQM}<5$ which implies that fecal contamination is zero on all these structures, hence a conservation of the microbiological quality of these waters.

However, although faecal contamination according to the
(MQI) is zero, we note the presence of certain bacteria in these waters. The variation of these bacteria is shown on the following spatial distribution maps (Figures 5 and 6).

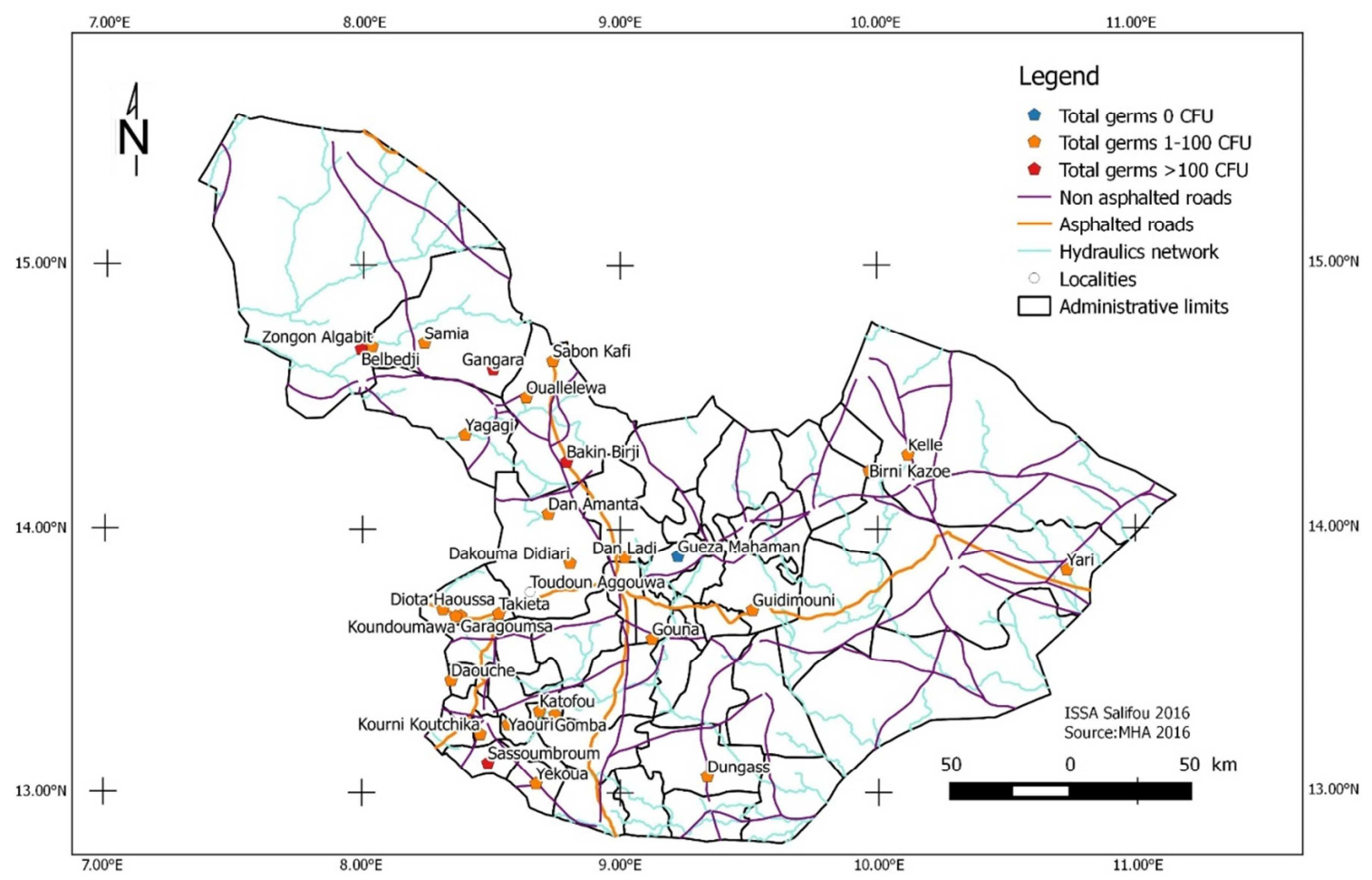

Figure 5. Total germs variation map of boreholes.

$96.67 \%$ of the samples taken from drinking water supply works in the Zinder area presents total germs TG $13.79 \%$ of these samples have more than $100 \mathrm{CFU}$ (colony forming unities) of total germs, $3.33 \%$ of the samples taken do not have total germs.

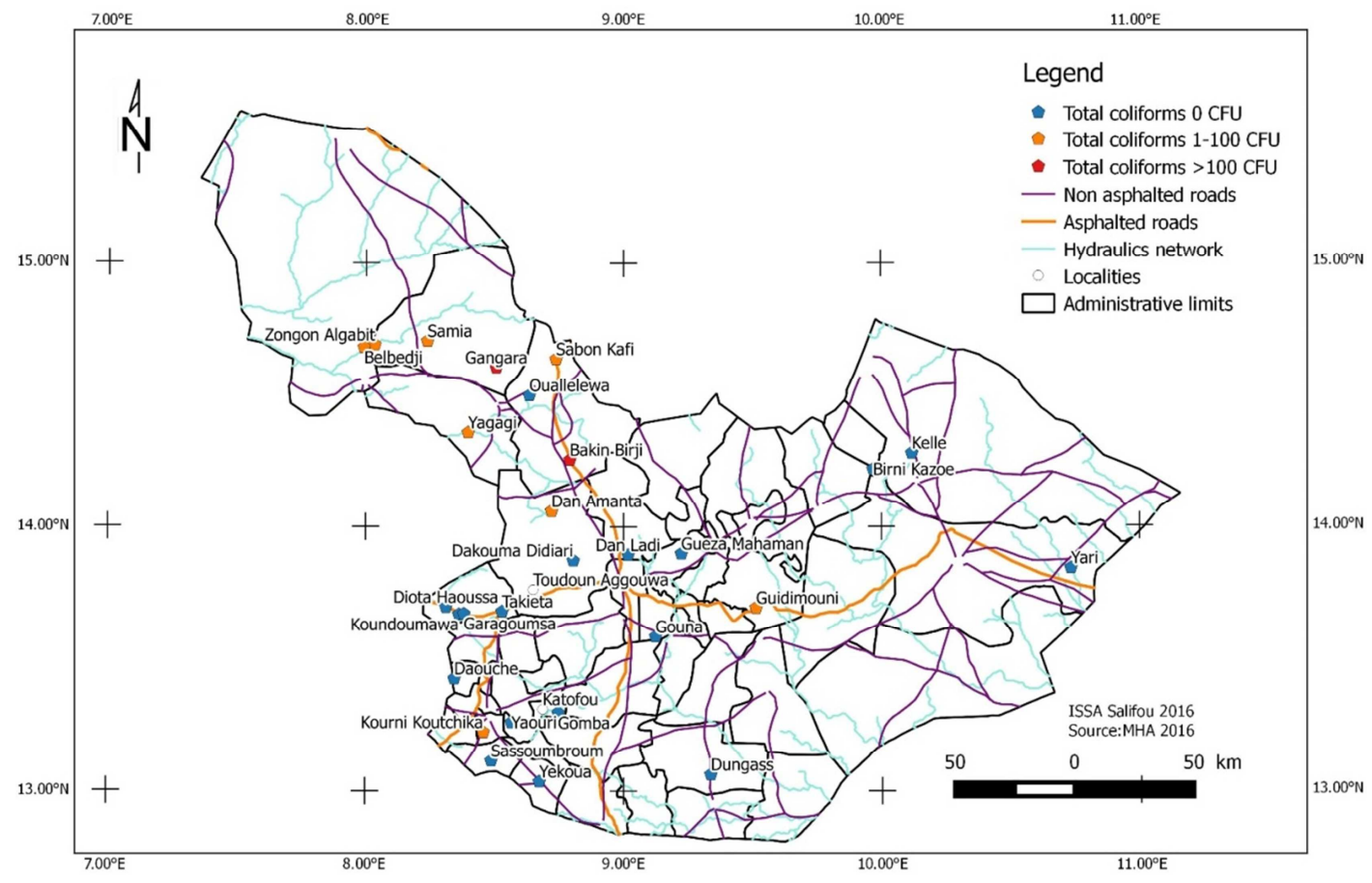

Figure 6. Map of Variation of Total Coliforms in Drilling Waters. 
$36.67 \%$ of the samples taken from drinking water supply works in the Zinder area have total coliforms. $18.18 \%$ of these samples have more than $100 \mathrm{CFU}$ of total coliforms, these results are similar to those of Mokofio et al, Aïssi, Comlanvi, Desjardins et Servais et al [13-17]. 63.33\% of the samples collected do not have total coliforms.

The variation of the results of bacteriological analyzes of the waters presented on these maps show that the majority of the samples taken were polluted by the presence of coliforms and total seeds, Hounsou et al [18] had the same observations in the waters of Benin.

In general, the presence of total coliforms in drinking water is a rather unspecific risk indicator of its quality. Usually, these bacteria can grow in a water distribution network whose drinking water production station is perfectly functional; this occurs from the microbial biofilm that forms on the wall of the pipes, especially when there is no or low residual chlorine $[19,20,21]$. In the context of a breakdown of the distribution network, coliforms can also be used as indicators of the integrity and the state of this network like other parameters (free residual chlorine and turbidity, for example) However, with respect to non-disinfected groundwater, the presence of total coliforms may be an indicator of the degradation of the quality of these waters caused by surface water inflow. Thus, total coliforms may be indicators of the potential presence of human enteric viruses $[22,23]$. In summary, total coliforms are primarily useful as indicators of treatment efficacy, distribution network integrity and as indicators of bacterial re-growth after treatment [24, 25].

According to the World Health Organization, total coliforms should be absent from the distribution network immediately after leaving the drinking water plant $[21,25$, 26], to ensure that the water supply is considered to meet the recommended threshold for drinking water.

In terms of quality, the bacteriological pollution of these structures is due to the lack of maintenance of these structures, to which must be added the lack of monitoring and the lack of knowledge of the bacteriological quality of these waters.

\section{Conclusion and Recommendations}

At the end of this study, the faecal contamination on the structures is not observed. The main trends show that these waters are contaminated with Total Germs (TG) and Total Coliforms (TC) with respectively $96.67 \%$ and $36.67 \%$ of the structures affected. However, the presence of these germs and coliforms in these waters makes them non-compliant with WHO recommendations. In addition, these two microbiological parameters (TG and TC) may involve the presence of a range of other bacteria germs, which can classify these waters as water unfit for human consumption. Thus, although groundwater is of better microbiological quality than surface waters, the fact remains that they may pose a risk to human health.
These results should challenge the structures involved in the production of drinking water in the study area, in particular the (Zinder Regional Direction of Hydraulics and Sanitation) ZRDHS and the Ministry of Hydraulics and Water Supply and Sanitation. These structures must take responsibility for the maintenance of the storage tank, the periodic and regular monitoring of the bacteriological quality of the water. They must install a device for the treatment of these waters at the outlet of the tank, or make populations awareness on the use of disinfectant before consumption of these waters. These measures will enable people to protect themselves from diseases linked to the microbiological pollution of water.

\section{References}

[1] Salifou I., Abdoukarim A., Zanguina A., Ibrahim N., Mousa B., Dominique S. and Daouda M. Hydrogeochemical Characterization of Continental Intercalary, Terminal, the base and the Korama Aquifers Groundwater found in fivenLocal Governments in the Zinder region in the Republic of Niger, Res. J. Chem. Env. Sci, 3 (4) 09-16(2015).

[2] Hounsou M. B., Agbossou E. K., Ahamide B. et Akponikpe I. Qualité bactériologique de l'eau du bassin de l'Ouémé: cas des coliformes totaux et fécaux dans les retenues d'eau de l'Okpara, de Djougou et de Savalou au Bénin, Int. J. Biol. Chem. Sci,4(2): 377-390(2010).

[3] Gantzer C. A. P., Audic J. M and Schwartzbrod L. Detection of infectious enteroviruses, enterovirus genomes, somatic coliphages, and Bacteroidesfragilis phages in treated wastewater, Appl Envron Microbiol 64: 4307-4312(1998).

[4] ONU. L'eau une responsabilité partagée, 2ème Rapport mondial des Nations Unies sur la mise en valeur des ressources en eau (2007). (www.unesco.org/ water/wwap/index_fr.shtml)

[5] Constantin M., Leroux R., Amable M-C., Mesnardrobbe A. et Rimbault C. L'eau en capitale. Paris Info(2007).

[6] Makoutodé M., Assani A. K., Ouendo E-M., Agueh V. D. et Diallo P. Qualité et mode de gestion de l'eau de puits en milieu rural au Bénin: cas de la sous-préfecture de GrandPopo. Médecine d'Afrique Noire,46 (11): 7(1999).

[7] Mérino M. L'eau: quels enjeux pour l'Afrique subsaharienne ? CREPAO, Note $\mathrm{n}^{\circ} 20$ de la Fondation pour la Recherche Stratégique (FRS), Université de Pau et des Pays de l'Adour (2008).

[8] Zogo D. Caractéristiques physicochimiques, bactériologiques et traitements des eaux de consommation en République Populaire du Bénin. Mémoire de fin d'étude, Collège Polytechnique Université d'Abomey-Calavi, Bénin(1980).

[9] Santé Canada. (2003) www.sc-hc.gc.ca ou http://www ou hcsc.gc.ca/ewhsemt/ pubs/water-eau/index-fra.php

[10] Hounsinou P., Mama D., Alassane A. and Boukari M. Hydrogeology and Chemistry Synthesis of the deep Boring of the Township of Abomey-Calavi, Benin, Res. J. Chem. Sci.4(12), 103-116 (2014). 
[11] Salifou I., Abdoukarim A., Ibrahim N., Mousa B., Dominique S. and Daouda M. Caractéristique hydrogéochimique des eaux souterraines des aquifères de l'Izegouandé et du Tarat au voisinage de la Somaïr à Arlit au Niger. J. Soc. Ouest-Afr. Chim, 039: 57-63(2015).

[12] SEEN. Protocoles de prélèvements et analyses de l'eau. Document interne, laboratoire d'analyses de l'eau de Zinder, Niger(2016).

[13] Mokofio F., Renaudet J., Opandy C., Bastard G., Abeye J., Yete ML., Touabe J., Gondao L., Vohito JA. Qualité bacteriologique de l'eau des puits, des sources et des forages dans la ville de Bangui. Premiers résultats et perspectives. Médecined'Afrique noire, 38 (11) (1991).

[14] Aïssi MJ. Impacts des déchets domestiques sur la qualité de la nappe phréatique à Cotonou. Mémoire: Aménagement, Protection de l'environnement: Abomey-Calavi, (1992).

[15] Comlanvi FM. Amélioration de la qualité des eaux des puits dans la ville de Cotonou: cas de quelques quartiers. Mémoire, Aménagement, Protection de l'environnement. Ab-Calavi, CPU, (1994).

[16] Desjardins R. Le Traitement des Eaux. 2è édition revue de l'Ecole Polytechniquede Montréal; 304(1997).

[17] Servais P., Garcia AT., Lizin P., Mercier P., Anzil A. Analyses des risques chimiques et microbiens, Sources et dynamique des coliformes fécaux dans l'estuaire de la Seine. Ecologies Systèmes Aquatiques, Seine Aval, Rapport Programme, (2003).

[18] Hounsou MB., Agbossou EK., Ahamide B. et Akponikpe I. Qualité bactériologique de l'eau du bassin de l'Ouémé: cas des coliformes totaux et fécaux dans les retenues d'eau de l'Okpara, de Djougou et de Savalou au Bénin.Int. J. Biol. Chem. Sci. 4(2): 377-390(2010).

[19] Camper AK, McFetters GA., Charackliset WG. Jones WL.
Growth kinetics of coliform bacteria under conditions relevant to drinking water distribution systems. Appl. Env. Microbiol, 57: 2233-2239(1991).

[20] LeChevallier MW., Welch NJ. et Smith DB. Full-scale studies of factors related to coliform regrowth in drinking water. Appl. Environ. Microbiol, 62: 2201-2211(1996).

[21] Santé Canada, Recommandations pour la qualité de l'eau potable au Canada; document technique, les coliformes totaux(2012)www.hc-sc.gc.ca/ewh-semt/alt_formats/hecssesc/pdf/pubs/water-eau/coliforms-coliformes/coliformscoliformes-fra.pdf (lien externe s'ouvrant dans une nouvelle fenêtre)

[22] Locas A., Barthe C., Margolin AB. et Payment P. Groundwater microbiological quality in Canadian drinking water municipal wells. Canadian Journal of Microbiology, 54: 472-478(2008).

[23] Payment P. et Locas A. Pathogens in water: value and limits of correlation with microbial indicators. Ground Water, 49: 411(2011).

[24] Robertson W. Utilités et limites des indicateurs microbiologiques de la qualité de l'eau potable. Dans: Air intérieur et Eau potable, sous la direction de Pierre Lajoie et Patrick Levallois, Presses de l'Université Laval, p. 179193(1995).

[25] WHO. Guidelines for drinking-water quality, Third edition incorporating the first and second addenda, volume 1 , Recommendations (2011). www.who.int/water_sanitation_health/dwq/gdwq3rev/en (lien externe s'ouvrant dans une nouvelle fenêtre)

[26] US EPA, Part 141. National primary drinking water regulations. United StatedEnvironmental Protection Agency (2002) (consulté le 14 novembre 2011) www.nmenv.state.nm.us/dwb/Documents/DWREGS/40\%20CFR\%20141\%20(7-02\%20edition).pdf (lien externe s'ouvrant dans une nouvelle fenêtre) 